\title{
Remembering Lugones: The Critical Potential of Heterosexualism for Studies of So-Called Australia
}

\author{
Madi Day $\mathbb{B}$
}

Department of Indigenous Studies, Macquarie University, Sydney 2109, Australia; madi.day@mq.edu.au

\begin{abstract}
Heterosexualism is inextricably tied to coloniality and modernity. This paper explores the potential of Argentinian philosopher Maria Lugones' theorisations of heterosexualism and the colonial/modern gender system for sustained critical engagement with settler colonialism in socalled Australia. 'Heterosexualism' refers to a system of relations between settlers and Indigenous peoples characterized by racialized and gendered power dynamics. Lugones' theory on the colonial/modern gender system unpacks the utility of social and intellectual investment in universalised categories including race, gender and sexuality. Such categories are purported to be biological, thus, prior to culture, settlers and colonial institutions. However, the culturally specific nature of knowledge produced about race, gender and sexuality reveals that the origins, and indeed the prevalence, of heterosexualism in Australia is inextricable from settler colonialism. This paper exhibits how heterosexualism and the colonial/modern gender system operate in service of settler colonialism, facilitating settler dominance and reproduction on Aboriginal and Torres Strait Islander lands.
\end{abstract}

Keywords: heterosexualism; settler coloniality; modernity

check for updates

Citation: Day, Madi. 2021. Remembering Lugones: The Critical Potential of Heterosexualism for Studies of So-Called Australia. Genealogy 5: 71. https://doi.org/ $10.3390 /$ genealogy5030071

Received: 7 May 2021

Accepted: 26 July 2021

Published: 30 July 2021

Publisher's Note: MDPI stays neutral with regard to jurisdictional claims in published maps and institutional affiliations.

Copyright: (C) 2021 by the author. Licensee MDPI, Basel, Switzerland. This article is an open access article distributed under the terms and conditions of the Creative Commons Attribution (CC BY) license (https:/ / creativecommons.org/licenses/by/ $4.0 /)$.

\section{Introduction}

No one slice of 'reality' can have univocal meaning

(Lugones 2003, p. 28)

The world of resistance is institutionally weaker but it is spirited in a long winded way

(Lugones 2014, p. 1)

As I began writing this article during lockdown in 2020, I learned of the death of Argentinian lesbian feminist and prolific philosopher, Dr. María Lugones. I first read Lugones's work in an issue of Hypatia; I purchased a print copy of the feminist philosophy journal from an op-shop while I was waiting for a bus home from work on Dharug country (North Sydney). This was in 2011, before I entertained the idea of higher education. I was working a trade, fitting and dispensing spectacles at an optometrist, living in my parents' back shed (I had sort of converted it into a home), and preparing to come out to my European ${ }^{1}$ and Aboriginal $^{2}$ family as a lesbian for a second time (their previous reactions had been so harsh that I reverted to dating men). I was not especially literate in academic language at the time, but I read second-hand books on philosophy for something to think about other than work or home life. I recall being so engrossed in Lugones's article that I continued to read it while I walked onto, rode and exited the bus. I sat down on some stairs in an alleyway on my way home to read the text carefully until the sun set and it became too dark to read. Revisiting Heterosexualism and the Colonial/Modern Gender System (Lugones 2007), I can remember how small and rigid the world then seemed, and how it expanded and its structures weakened as I read work that both imagined and articulated alternative models of social order. The importance of Lugones's collective works for methen and now-lies in the insistence on a world much older, broader and more complicated than the modern/colonial heterosexual realities that dominate the world in which I am embedded. 
Ten years later, I continue to be inspired by Lugones as a writer, an educator, an organiser and a thinker. With this article, I join a genealogy of scholarship impacted by her studies of European colonialism, modernity, race, sexuality and gender. Lugones's interdisciplinary and activist approach to philosophy, particularly feminist philosophy, earnt her international acclaim. She describes her own work as 'theoretico-praxical' (Lugones 2007, p. 186)theory designed for application. Her students and colleagues describe her as deeply committed to coalition and community building, and collective change in both her career and personal life (Micale 2020). This approach succeeds her, living on through the enduring global use and relevance of her work. In thinking through the application of Lugones' work, I begin this article by considering the compatibility of this approach with Indigenous Studies in so-called Australia. I then provide an overview of Lugones's related frameworks of heterosexualism and the coloniality of gender. I contemplate the co-constitutive relationship between heterosexualism as a racialized practice revolving around the reproduction and universalisation of European colonialism, and settler colonialism as a structure that eliminates Indigenous peoples and lifeways in order to replace them with settlers and their systems (Wolfe 2008). In doing so, I emphasise the cultural specificity of heterosexualism and its origins in European modern/colonial science, and its role in the production and continuation of Australia as a settler colonial state. Finally, I consider future applications of heterosexualism to studies of settler colonialism and Australian society and culture at large.

\section{Lugones and Indigenous Studies in So-Called Australia}

Lugones' work aims to illuminate and resist logics of domination, and explore how subjects enmeshed in these logics conceptualise and tactically oppose them. She is critical of dichotomies, the dichotomy of the oppressor/oppressed in particular. Her writing draws on relational ontologies to explain the dynamism of collectives and coalitions of peoples who have distinct 'worlds of sense', which Lugones describes as diverse perspectives existing and resisting in relation to hegemonic power and narratives (Lugones 2003, p. 5). She describes subjects (including herself) as actively producing logics within multiple layers of 'relationships, institutions and practices' (ibid.). In this way, Lugones' thinking is deeply compatible with Aboriginal ontologies and, in particular, with Aboriginal conceptualisations of holism and relationality. Holism, Palyku scholar Ambelin Kwaymullina explains, is an important concept underpinning Aboriginal Australian worldviews that involves understanding life as a 'pattern that has many threads of many colours' (Kwaymullina 2005, p. 12). Kwaymullina elaborates: 'This is the pattern of reality created by the Ancestors. It exists within and between all life, and is grounded in Aboriginal Countries' (Kwaymullina 2018, p. 146). Relationality, as explained by Kombumerri and Wakka Wakka political philosopher Mary Graham, is a system of total interconnectedness that orders the societies and realities of Aboriginal peoples. Land custodianship and mutual obligation between all lifeforms underpin this system. It is also a logic comprised of respect for autonomy, balance and multiplicity (Graham 2014). While European worldviews individualise, hierarchize and universalise, holism and relationality allow for multiple, connected, and equally valuable perspectives, and even simultaneous worlds of sense.

Lugones's insistence on ontological multiplicity draws attention to the cultural specificity of imposed colonial orders. She encourages coalition building between resistant subjectivities (marginalised people with resistant intentionality) to collectively address hegemonic organisations of power (Lugones 2003, 2010). She sees this position of resistance as the starting point for decolonial feminism. In this way, her work is compatible with current directions of Indigenous Studies in Australia. Goenpul scholar and feminist, Aileen Moreton-Robinson highlights a shift in Indigenous Studies in recent years towards an interdisciplinary approach. She draws from Martin Nakata and Chris Anderson, to argue that to expand the 'conditions of possibility', Indigenous scholars must move beyond research about Indigenous peoples and communities that reiterates Indigenous objectification and cultural difference (Moreton-Robinson 2015, pp. xv-xvi). Rather than limiting Indigenous studies to endogenous examinations of culture, community, governance and land, she en- 
courages Indigenous researchers to leverage our complex positions within colonial society, to deploy both Western and traditional knowledges, and to engage in sustained intellectual analyses of hegemony, colonial institutions and Western conceptualisations of Indigeneity. Like Lugones, Moreton-Robinson argues for a shift in research focus from exploring the cultural difference of other-than-white people to an approach utilising interdisciplinary means of critiquing whiteness and colonialism to decolonial ends (pp. xvii-xxi). Lugones describes this approach to scholarship in terms of collaboratively exploring and understanding oppressive systems in order to collectively subvert and dismantle them (Lugones 2010). This combined interdisciplinary and collaborative approach offers new possibilities for research into to the specifities, complexities and interdependencies of heterosexualism, racialization and colonialism in so-called Australia.

Critical engagement with gender, sex and sexuality is a point of connection for Indigenous peoples surviving and resisting Anglo-settler nation-states. As I have discussed elsewhere (Day 2020), Indigenous queer studies in so-called Australia is both intimately connected with, and distinct from Two-Spirit and Native Studies on Turtle Island (Canada and USA). Aboriginal and Torres Strait Islander scholars cultivate a unique interdisciplinary research culture where Indigenous Studies can be broadly described as research and scholarship by and of interest to Aboriginal and Torres Strait Islander people. Research in this discipline is evaluated in terms of its benefit to communities, and its contribution to futures and self-determination for Aboriginal and Torres Strait Islander people (ibid. p. 369). This culture emerged from a distinct political environment that resulted in the activism and work of key theorists including Aileen Moreton-Robinson, Margaret Walter, Irene Watson, Jackie Huggins, Martin Nakata and Lester Rigney. In this specific context, Indigenous queer scholarship is most often academic work by queer and transgender Aboriginal and Torres Strait Islander people that necessarily critiques settler colonialism and its bearings. With this article, I join a growing cohort of thinkers who have built on foundations laid by O'Sullivan $(2015,2016,2019 a, 2019 b, 2021 a)$ to engage in transdisciplinary practice and scholarship that centers Indigenous queer and trans standpoints. This cohort includes but is not limited to Sullivan (2018a, 2018b, 2020), Clark $(2015,2017)$ and Farrell $(2015,2016,2021)$. This scholarship has been informed and influenced by Two Spirit critiques and literature studies (Driskill 2011; Tatonetti 2014), as well as Indigenous queer and feminist thinking around body sovereignty, resurgence and relationality (Wilson 2015; Simpson 2017; TallBear and Wiley 2019). Like Lugones, Aboriginal and Torres Strait Islander scholars also draw heavily from Black feminists as we continue to articulate racialized, gendered and politicized experiences as both Black and Indigenous peoples (Huggins 1995; Moreton-Robinson 2000; Bond 2019; Carlson 2020b). Not only is Lugones's interdisciplinary approach compatible with Indigenous Studies, but her close analysis of heterosexualism as a racialized system of dehumanization steeped in coloniality and modernity illuminates new and more complex approaches to studies of gender, sex and sexuality in the Australian context.

\section{Heterosexualism and the Colonial/Modern Gender System}

For Lugones, both colonized subjects (Indigenous peoples and racialized others) and colonisers (white Europeans) produce and are produced by the modern/colonial gender system. The production of a hierarchal dichotomy of human and non-human is central to this. The white European man is the most civilised and most significant human, labelled fit for ruling over all other life forms, including the white European woman who is relegated to the private domain where her subjugation and sexual purity operate to reproduce his race and protect his capital (Lugones 2010, p. 743). Within the modern/colonial gender system, the colonising man conceptualises himself as closer to mind and God, and conceptualises colonized subjects as close to the natural world and body-inherently sexual, beastlike and non-human. Colonized people, labelled non-human in the context of modernity and coloniality, are categorised male or female rather than men or women. Any person who is divergent within this model is categorically erased-eliminated both 
physically and ideologically. The modern/colonial gender system relies on a hierarchical, dichotomous, categorical logic to produce civil human men and women, and savage non-human males and females (Lugones 2010, p. 743). Sexual dimorphism is crucial to this system as colonised males and females are understood in terms of biological sexual nature rather than cultural roles ascribed to humans. Lugones argues that in this way the modern/colonial gender system denies colonised subjects gender as a denial of their full humanity (p. 744). The imposition of the modern/colonial gender system is foremost a process of reduction and dehumanisation in such a way that justifies immense cruelty and 'the civilising mission' (pp. 744-45).

Lugones insists that gender and coloniality are co-constitutive. Rosa Icaza has emphasized Lugones' assertion that gender distinguishes those understood as civilised and fully human (men/women) and those considered non-human (male/female/other) and thus exploitable and disposable to colonisers and their regimes. Lugones sees the construction of sexual difference as critical to the characterisation of civilised men and women, reflecting on the great medical and bureaucratic lengths taken to distinguish the two sexes in Western societies (Lugones 2007, pp. 194-95). Icaza explains 'Gender is then a characteristic of humanity imposed as a sexual order differently according to racial lines' (Icaza 2018, p. 67). She argues that the coloniality of gender exposes a logic of categorisation and dehumanization that ultimately determines which bodies are vulnerable to genocide. Icaza reiterates Lugones's framing of heterosexualism as an organising principle of this logic (Lugones 2007, pp. 205-6). The coloniality of gender thus theoretically frames heterosexualism not as a social practice nor as sexual preference informed by normativity, but as an organising system of dehumanization, subordination and exploitation of colonised peoples, critical to the reproduction of colonial dominance.

Heterosexualism is a key component of global projects of colonisation and civilising missions. Lugones describes the colonial civilising mission as one of transformation rather than humanisation. That is to say, colonial civilising forces do not aim to make non-humans more human. Rather, colonists brutally impose ideological frameworks that facilitate access to colonised bodies for sexual and physical exploitation, controlled reproduction, elimination and 'systematic terror' (p. 744). Christianity has a critical role in the civilising mission, leveraging the modern/colonial gender system as a form of judgement in order to transform the memories and identities of colonised subjects to such an extent that it also transforms their worldviews, relationships and cosmologies (p. 745). Heterosexualism occurred in this way in Native institutes and residential schools, where Christian missionaries enculturated Indigenous children in gendered roles, worldviews, and values regarding natural/moral sexuality (Simpson 2014). According to Lugones, the shift from theology as an organising force in colonialism to science as the driving force behind coloniality/modernity resulted in a conflation of moral/natural in relation to heterosexualism. Where once gender roles and heterosexuality were enforced by solely Christian morality, they were reinforced as rationally and scientifically essential according to a natural order of attraction and reproduction (p. 745). Lugones argues that the modern/colonial concept of nature 'reconceives humanity and human relations' in biological terms (Lugones 2007, p. 190). We see this for instance in the founding of the Black Town Native Institute, the first site of institutionalisation of Aboriginal people in Australia. Governor Lachlan Macquarie formed the institute in collaboration with missionary William Shelley as an experiment in bringing order and civilisation to Aboriginal societies (Brook and Kohen 1991). Indoctrinating children in this institution worked to introduce social classification in such a way that European human classifications including gender and race were accepted as natural or universal. Modernity and colonialism thus relied on the civilising mission to naturalise categories such as gender, sex and race, and 'the mythical presentation of these elements as metaphysically prior' (p. 191) as well as separate or unrelated.

Modernity and coloniality depend on the naturalisation and universalisation of knowledge to assert global power. Lugones utilises Anibal Quijano's model of modernity and coloniality as two structural axes of global, Eurocentred power to conceptualise the en- 
meshed nature of gender and race. She sees coloniality as an 'encompassing phenomenon' that pervades every level of power (p. 190). Coloniality relates to but is not the same as colonialism. Coloniality, Lugones writes, is constituted of and by all power relations that control human existence, including 'sex, subjectivity, authority and labour' and is thus irrevocably connected to capitalism (p. 191). Modernity, in this model, is constituted of and by the production of Eurocentric knowledge. This knowledge emerges from seventeenth century Europe in countries such as Holland, France and England, producing hegemony through the universalisation of this specific perspective (p. 191). Sciences of human life and behaviour have played a critical role in this project. Anthropologists most notoriously have produced significant bodies of knowledge on colonised peoples from colonial positions. In Australia, colonial anthropologists rapaciously surveyed Aboriginal identities, behaviours and relationships, framing our lifeways as antiquated and preserved in primitive conditions due isolation thus 'capable of casting light on the evolution of human races' (Smith 1913, p. 374). Heterosexualism is pertinent to anthropology as gender and sexuality function in the production of race. Anthropologists simultaneously produced and naturalised heterosexuality and gender relations in their representations of Aboriginal people. Despite the existence of complex, multi-faceted and diverse kinship systems among Aboriginal peoples (Graham 2008; Kwaymullina and Kwaymullina 2010; Carlson 2020a) colonists applied their own categories and power relations as universally applicable. Some of the most influential European thinkers including Darwin, Marx, Engels, and Freud referred to studies of colonised peoples and societies in their widely adapted conceptualisations of human nature, sexuality, family, governance, property and civilisation (Hiatt 1996, pp. 57-77). In this way, coloniality and modernity operate together, simultaneously producing categories such as gender and race, and naturalising European knowledge and power as rational and relevant despite cultural or temporal context.

The colonial/modern gender system is organised around sexual dimorphism, patriarchy and heterosexuality. Relative to race science, sexual dimorphism relies on phenotypical attributes as evidence of inherent difference and inferiority (Sommerville 1994). Lugones emphasises the significance of biology to colonial/modern practices, and argues that modern scientific practices of ascribing gender according to specific physical traits work to naturalise Eurocentric social constructions of civilised men and women, and racialized anatomical males and females (pp. 195-97). She draws on the work of Oyěwùmí (1997) who shows how colonists transformed Yoruba society by introducing a racialized sex/gender binary. Lugones agrees with Oyěwùmí that the continued transcultural relevance of patriarchy is intimately tied to Western global material dominance resulting from coloniality (Lugones 2007). Oyěwùmí argues that colonisers introduced race and gender as accompanying categories of inferiorization in African countries, and that Yoruba men embraced the inferiorization of women as a point of collusion with European men. She writes "The creation of "women" as a category was one of the very first accomplishments of the colonial state... The transformation of state power to male-gender power was accomplished at one level by the exclusion of women from state structures. This was in sharp contrast to Yoruba state organization, in which power was not genderdetermined' (Oyěwùmí 1997, pp. 123-25). In Australia as well as other Anglo settler colonial nations, there is substantial evidence to suggest that patriarchal structures of governance, property and intimacy have been introduced to Indigenous peoples and societies through gendered enculturation and civilising projects including Christian missions and, medical and educational institutionalisation (Graham 2014; Moreton-Robinson 2015; Simpson 2017). Colonial categorisation of people along a strict binary of sexual difference, and according to gendered hierarchy continues to result in damage to relationships among Indigenous peoples, and state-sanctioned gendered and racialized violence against Indigenous women and, queer and transgender peoples (Carlson and McGlade in Gregoire 2021; Carlson and Day 2021; Carlson 2021). Building on the work of Oyěwùmí, Lugones emphasises the pertinence of sexual dimorphism in the implementation of patriarchy at economic, political and cognitive levels (Lugones 2007, p. 198) as part of the process of colonisation. 
Heterosexualism then is not only a gendered and racialized dynamic between colonised peoples and colonisers, but also among colonised people with one another.

Lugones argues that heterosexualism is a dynamic between European men and women that is reinforced by power relations between colonisers and colonized peoples. She draws on the work of Collins (2000) to demonstrate how 'femininity' is a quality largely reserved for white upper and middle-class women, and unavailable to Black, Indigenous and working-class women (Lugones 2007, p. 205). For Lugones, heterosexualism is racialized and, race and racial difference are articulated through gender and sexuality. Both sexuality and racialisation have historically been evaluated by colonial sciences in terms of congenital degeneracy-biological predisposition to sexual vices measured through comparative anatomy (Sommerville 1994). This has been especially true in the sexualisation and gendered racialisation of Black women. Colonial science has defined sexual deviance in relation to race. Colonial biologists, sexologists and psychologists utilised comparative anatomy to deduce that people who were more 'evolved' had more differentiated sexual characteristics, and that incidences of intersexuality (referred to then as hermaphroditism) implied persistence of or degeneration towards a primitive state (p. 29). In the United States, colonial biologists, psychologists and race scientists compared the genitals of white women accused of lesbianism to the genitals of African American women (pp. 25-27). Sexual racism and scientific articulations of deviant and normal sexuality emerge along comparative timelines from disciplines intimately tied to coloniality.

Heterosexualism ascribes white women sexual passivity and purity, and smallness and weakness in body and mind. In this dynamic, white men protect white women as a means of control of (re)production. Colonized peoples are racialised by heterosexualism and ascribed greater physical size and strength, and excessive sexual appetites by colonisers who exploit them both sexually and in terms of labour. In Australia, for instance, we have seen how this logic operates in Jackie Huggins's accounts of abuse of Aboriginal women and girls in stock work and domestic servitude (Huggins 1987, 1995). White settler women were relegated to the home by white settler men for protection and subservience where they were also complicit in the sexual and physical exploitation and abuses of Aboriginal women and children. The colonial/modern gender system constructs both colonised males and females as sexually voracious and aggressive, enabling white men to maintain status as sexual protectors of white women, and for simultaneous brutal and unrestrained access to colonised bodies (Lugones 2007, pp. 205-6). Heterosexualism orders racialized power relations within the colonial/modern gender system, reinforcing colonial authority and control over sex, labour and production.

Lugones's conceptualisations of heterosexualism and the colonial/modern gender system infer that hierarchical categories of inferiority and domination such as gender and race never 'travel away from' colonial modernity (Lugones 2010, p. 746). Coloniality/modernity prevail as global power, imposing upon the lives, bodies and realities of colonised peoples. Eurocentric knowledge of life universalises in such a way that it reconceives humanity and human relations as 'naturally' hierarchical and dichotomous. Thus, naturalised constructions of race, gender and sexuality seem ubiquitous even though they are fundamentally colonial impositions. These categories are mechanisms of dehumanisation and dispossession, introduced through brutal processes such as the Christian civilising mission and invasive colonial sciences of human observation and categorisation. Coloniality and modernity operate in tandem to decimate Indigenous social orders, worldviews, cosmologies and identities for the benefit of colonisers and their entities. Heterosexualism draws attention to binaries of man/woman, male/female, coloniser/colonised, and civilised/primitive, and how these are ultimately produced interdependently and in relation to the status of human/non-human in the context of coloniality/modernity. Lugones implores us to take issue with and unpack these categorisations as temporally, culturally and geographically specific rather than universal, and irreversibly connected through the colonising practices and parties. 


\section{Applying Heterosexualism to Australian Settler Colonialism}

Heterosexualism as a critical framework highlights the integral function of sex, gender and sexuality in modernity and coloniality. Lugones offers this as a starting point for practical theoretical approach to interrogation, deconstruction and resistance (p. 747). She implores us to take heterosexualism forward to use in collective action against hegemony, and to 'enact a critique of racialized, colonial, and capitalist heterosexualist gender oppression as a lived transformation' (p. 746). From my own standpoint as a resistant subject within layers of 'relationships, institutions and practices' (Lugones 2003, p. 5), I am interested in the social, political and epistemological potential of heterosexualism in critiques of settler colonialism in Australia. Although they are typically concomitant, settler colonialism and colonialism differ primarily in terms of subordination vs. elimination. While colonialism works to keep Indigenous peoples permanently subordinated for the purpose of exploitation, settler colonialism works to eliminate Indigenous peoples by means of actual, cultural, social, and ideological extermination towards the end of supersession (Veracini 2011). Australia as a settler colonial state operates on an outlook of permanencethe term settler in itself implies they are here to stay (p. 6). Settler colonialism in Australia is enacted through systematic interference in and officious regulation of Aboriginal people's relationships, sexualities and lives as a sustained attack on the foundations of our societies and existence. There is significant scholarship from Aboriginal and Torres Strait Islander and settler academics around the denigration and decimation of Aboriginal and Torres Strait Islander families, social systems and identities as strategic settler colonial practice (Ellinghaus 2003; Nakata 2004; Moran 2005; Fredericks 2010; Veracini 2011; Haebich 2015; Carlson 2021). Increasingly, there is also critical work from Aboriginal queer and transgender scholars on Christianity and settler sexuality, and the harm and erasure enacted on Aboriginal people, identities and relationships (Sullivan 2018b; Day 2020; Coleman 2020; O'Sullivan 2021b). Thus far, however, there has been limited engagement with heterosexualism and gender as functional components of settler colonialism in Australia.

Heterosexualism offers exciting possibilities for scholarship in Indigenous Studies and settler colonial studies in Australia. Unpacking the specifics of heterosexualism as they relate to the production of knowledge and power interrogates constructions such as gender, race, Indigeneity and sexuality in a manner that is simultaneously broader than and inclusive of studies of representation and identity. Sustained engagement with the geographical, temporal and cultural specificities of sex, gender and sexuality, and their inseverable relevance to modernity and coloniality call into question the global dominance and relevance of these ontologies and epistemologies. Modernity, as knowledge that evaluates and controls the validity of other epistemologies and ontologies (Lugones 2007, p. 191), has been weaponised by settlers against Aboriginal peoples. Aboriginal ontologies and epistemologies are conceptualised as pre-modern compared to the impositions of Western standpoints, which are framed as more progressive, more rational and more contemporary rather than temporally and culturally specific. This is evident in representations of Aboriginal gender and sexuality in the fields of sociology, anthropology and psychology that continue to influence broader discourses about race, human sexuality and nature. Aboriginal social orders and behaviours are consistently framed as base, licentious and primitive (see Totem and Taboo by Freud 2001 for instance, or see Hiatt 1996 for an overview of these representations in anthropology), and relationships between Aboriginal men and women are represented as dysfunctional and violent (Conor 2013; Bond 2019). Such knowledge disguises the deeply embedded nature of gendered and sexual violence in settler colonialism (Meiu 2015; Deer 2009). Evaluating knowledge about sex, gender and sexuality as specific to modernity and coloniality, thus in service of settler colonialism, expands the possibilities for addressing the gendered nature of settler colonialism. Heterosexualism is one framework we can use to explore the specificity and plurality of knowledge about sexuality and gender, to illuminate colonial power and to challenge the neutrality and permanence of settler colonial disciplines and institutions. 
Adopting this approach to the conceptualisations of sex, gender and sexuality that dominate our current realities, we are positioned to investigate how these ideas serve the interests of settlers and the settler colonial state. We can begin by asking: if settler colonialism relies on the actual, cultural, social, and ideological extermination of Indigenous peoples and lifeways then what is the role of heterosexualism in this process? The answer to this has played out in my own life in the same way I imagine it is has in many Indigenous peoples' regardless of their gender identity or sexual preferences: through gendered and racialized violence from settlers and settler institutions, through dispossession from land, from community and from culture, and through harm between and against Aboriginal people. Investigating each of these manifestations of heterosexualism in service of settler colonialism in detail is beyond the scope of this article. I will explore this further in future publications and throughout my PhD. I also invite other Aboriginal scholars to apply heterosexualism as a critique of the settler colonial apparatuses that intervene in our lives. We might start with the meticulous regulations and interventions in Aboriginal peoples' relationships, sexualities, families and marriages by the Aborigines Protection Act, and the Aboriginal Welfare Board up until 1969. We could address how heterosexualism continues to operate in the evaluation of Aboriginal families and caregivers and the justification of child removal by the settler colonial state. We could also consider the role of 'traditional' family structures and genealogies in claims for land rights and Native Title, and the resulting disenfranchisement and dispossession of certain people and communities. Once we begin unpacking settler colonialism as a gendered and sexualised phenomenon it is difficult to find elements and layers untouched by heterosexualism. There is plenty to unpack in how heterosexualism operates through controlled reproduction, biological absorption and selective pro-natalism to reinforce the settler dominance and the setter colonial state, and the interplay between this and settler ableism (King et al. 2014; Soldatic 2015). We might also query our own investments in gendered power relations and heterosexual monogamy, and ask: what are the possibilities for our own relationships, families, lives and communities beyond the gendered and racialized constraints of coloniality and modernity? There are innumerable questions to be asked and answered about how heterosexualism functions to perpetuate the dehumanization, decimation, and dispossession of Aboriginal people in service of the continuation of the settler colonial state.

\section{Conclusions}

Lugones shared Foucault's sentiment that 'where there is power, there is resistance' (Foucault 1990, p. 95) - dominance never goes uncontested and there will be always tension between the oppressing and the resisting (Lugones 2010, p. 748). She did not see this as a dichotomy between two warring parties. She saw the potential of coalitions of resistance with differing perspectives but common goals in addressing hegemony. Like power, she saw resistance as decentralised and dispersed-it 'infiltrates every aspect of living' (p. 754). Lugones argued that the multiplicity of resistance builds and sustains effective coalitions, and that the plurality of knowledge challenges both the concreteness and universality of colonial power, making transformation, adaptability, rejection, and other forms of creative agency and shared ways of understanding the world possible (p. 755). There is no one way to challenge hegemony. Lugones believed that it could be 'fractured' by diverse and heterogeneous forms of resistance (ibid.). This is her legacy. Her political, intellectual work continues, utilised in intellectual engagements with hegemony and colonialism around the world (Moya 2006). Her insistence on ontological multiplicity, the subversion of hegemony through coalitions of resistant subjectivities, and her conceptualisations of heterosexualism and the colonial/modern gender system still have much to offer Indigenous and decolonial studies of global Eurocentric capitalist powers. Heterosexualism and the coloniality of gender as theoretical frameworks to comprehend settler colonialism open new directions in research in Indigenous Studies in so-called Australia. These directions require Indigenous researchers to use our complex positions in relation to settler colonialism and heterosexualism to query the relationship between 
the two, but also to consider how these systems influence our relationships with each other and other colonised peoples. Lugones' framework makes room for collaborations between interdisciplinary knowledges with connected positions and goals. Interrogating heterosexualism as an integral component of settler colonialism in so-called Australia produces exciting and challenging questions about the epistemological and ontological specificity of human sciences and studies of human relations. Indigenous scholars are uniquely positioned to resist the universalisation of hierarchical categories assumed separate and 'natural' despite culture, time and place. Heterosexualism as a critical framework offers new 'conditions of possibility' (Anderson in Moreton-Robinson 2015, pp. xv-xvi) for studying coloniality and modernity as they constitute Australia as a settler colonial society and state.

Funding: There was no funding for this project.

Institutional Review Board Statement: Not applicable.

Informed Consent Statement: Not applicable.

Data Availability Statement: Not applicable.

Acknowledgments: I would like to thank the editors of this special edition Bronwyn Carlson and Tristan Kennedy for their ongoing support in my studies and career.

Conflicts of Interest: The author declared no conflict of interest.

\section{Notes}

1 Many Indigenous people do not identify with their European heritage/ancestors. I feel that it would be remiss of me to ignore my settler heritage, as it is significant to my worldview. Catholicism and European values impinged greatly on my life and shaped my understanding of race, gender, and heterosexuality and settler colonialism.

2 In this chapter, I focus on experiences and ontologies relevant to Aboriginal peoples. This is due my own standpoint as well as the scope of this research. I invite Torres Strait Islander researchers and writers to determine whether Lugones' analysis is useful or appropriate for you.

\section{References}

Bond, Chelsea. 2019. Talkin'Down to the Black Woman. Australian Feminist Law Journal 45: 185-89. [CrossRef]

Brook, Jack, and James Kohen. 1991. The Parramatta Native Institution and the Black Town: A history. Kensington: New South Wales University Press.

Carlson, Bronwyn. 2020a. Indigenous Killjoys Negotiating the Labyrinth of Dis/Mistrust. In Critical Reflections and Politics on Advancing Women in the Academy. Pennsylvannia: IGI Global, pp. 105-23.

Carlson, Bronwyn. 2020b. Love and hate at the Cultural Interface: Indigenous Australians and dating apps. Journal of Sociology 56: 133-50. [CrossRef]

Carlson, Bronwyn. 2021. 'Data silence in the settler archive: Indigenous femicide, deathscapes and social media'. In Mapping Deathscapes: Digital Geographies of Racial and Border Violence. Edited by S. Perera and J. Pugleise. London: Routledge.

Carlson, Bronwyn, and Madi Day. 2021. Technology-facilitated abuse: The need for Indigenous-led research and response. In Technology and Domestic Violence: Victimisation, Perpetration and Responses. Edited by Bridget Harris and Delanie Woodlock. London: Routledge.

Clark, Maddee. 2015. Indigenous subjectivity in Australia: Are we queer? Journal of Global Indigeneity 1: 7.

Clark, Maddee. 2017. Becoming-with and together: Indigenous transgender and transcultural practices. Artlink 37: 76-81.

Coleman, Claire. 2020. Aboriginal Feminism and Gender. NGV. Available online: https://www.ngv.vic.gov.au/essay/aboriginalfeminism-and-gender/ (accessed on 7 August 2020).

Collins, Patricia Hill. 2000. Black Feminist Thought. New York: Routledge.

Conor, Liz. 2013. 'A species of rough gallantry': Bride capture and settler-colonial print on Australian Aboriginal gender relations. Settler Colonial Studies 3: 6-26. [CrossRef]

Day, Madi. 2020. Indigenist Origins: Institutionalizing Indigenous Queer and Trans Studies in Australia. Transgender Studies Quarterly 7: 367-73. [CrossRef]

Deer, Sarah. 2009. Decolonizing rape law: A native feminist synthesis of safety and sovereignty. Wicazo Sa Review 24: 149-67. [CrossRef]

Driskill, Qwo-Li, ed. 2011. Queer Indigenous Studies: Critical Interventions in Theory, Politics, and Literature. Tuscon: University of Arizona Press.

Ellinghaus, Katherine. 2003. Absorbing the 'Aboriginal problem': Controlling interracial marriage in Australia in the late 19th and early 20th centuries. Aboriginal History 27: 183-207. [CrossRef]

Farrell, Andrew. 2015. Can you see me? Queer margins in Aboriginal communities. Journal of Global Indigeneity 1: 3. 
Farrell, Andrew. 2016. Lipstick clapsticks: A yarn and a Kiki with an Aboriginal drag queen. AlterNative: An International Journal of Indigenous Peoples 12: 574-85. [CrossRef]

Farrell, Andrew. 2021. Feeling Seen: Aboriginal and Torres Strait Islander LGBTIQ+ Peoples,(In) Visibility, and Social-Media Assemblages. Genealogy 5: 57. [CrossRef]

Foucault, Michel. 1990. History of Sexuality Vol. 1, An Introduction. New York: Vintage.

Fredericks, Bronwyn. 2010. What'em with the apology?: The National Apology to the Stolen Generations two years on. Journal of Australian Indigenous Issues 13: 19-29.

Freud, Sigmund. 2001. The Complete Psychological Works of Sigmund Freud Vol. 13: Totem and Taboo and Other Works. London: Random House, vol. 13.

Graham, Mary. 2008. Thoughts about the Philosophical Underpinnings of Aboriginal Worldviews in Australian Humanities Review, Issue 4. ANU E Press Retrieved 22: 181-92.

Graham, Mary. 2014. Aboriginal notions of relationality and positionalism: A reply to Weber. Global Discourse 4: 17-22. [CrossRef]

Gregoire, Paul. 2021. State-sanctioned Violence against First Nations Women: An Interview with Professors Carlson and McGlade. Sydney Criminal Lawyers. March 24. Available online: https://www.sydneycriminallawyers.com.au/blog/state-sanctionedviolence-against-first-nations-women-an-interview-with-professors-carlson-and-mcglade/ (accessed on 11 August 2020).

Haebich, Anna. 2015. Neoliberalism, settler colonialism and the history of indigenous child removal in Australia. Australian Indigenous Law Review 19: 20-31.

Hiatt, Lester Richard. 1996. Arguments about Aborigines: Australia and the Evolution of Social Anthropology. Cambridge: Cambridge University Press.

Huggins, Jackie. 1987. Firing on in the Mind: Aboriginal Women Domestic Servants in the Inter-War Years. Hecate 13: 5.

Huggins, Jackie. 1995. White aprons, black hands: Aboriginal women domestic servants in Queensland. Labour History 69: 188-95. [CrossRef]

Icaza, Rosa. 2018. Social Struggles and the Coloniality of Gender. In Routledge Handbook of Postcolonial Politics, 1st ed. London: Routledge, pp. 58-71.

King, Julie, Brough Mark, and Knox Maree. 2014. Negotiating disability and colonisation: The lived experience of Indigenous Australians with a disability. Disability and Society 5: 738-50. [CrossRef]

Kwaymullina, Ambelin. 2005. Seeing the Light: Learning, Aboriginal Law and Sustainable Living in Country. Indigenous Law Bulletin 6: 12-15.

Kwaymullina, Ambelin. 2018. Literature, resistance, and First Nations futures: Storytelling from an Australian Indigenous women's standpoint in the twenty-first century and beyond. Westerly 63: 140-52.

Kwaymullina, Ambelin, and Blaze Kwaymullina. 2010. Learning to read the signs: Law in an indigenous reality. Journal of Australian Studies 34: 195-208. [CrossRef]

Lugones, Maria. 2003. Pilgrimages/Peregrinajes: Theorizing Coalition against Multiple Oppressions. Maryland: Rowman and Littlefield.

Lugones, Maria. 2007. Heterosexualism and the colonial/modern gender system. Hypatia 22: 186-219.

Lugones, Maria. 2010. Toward a decolonial feminism. Hypatia 25: 742-59. [CrossRef]

Lugones, Maria. 2014. Indigenous Movements and decolonial feminism. Seminario de grado y posgrado, Department of Women's, Gender and Sexuality Studies, The Ohio State University. Available online: https://wgss.osu.edu/sites/wgss.osu.edu/files/ LugonesSeminarReadings.pdf (accessed on 10 August 2020).

Meiu, George Paul. 2015. Colonialism and sexuality. The International Encyclopedia of Human Sexuality 1: 197-290.

Micale, Jennifer. 2020. Thought and Practice: María Lugones leaves global legacy. BingUNews. Available online: https://www. binghamton.edu/news/story/2580/thought-and-practice-maria-lugones-leaves-a-global-legacy (accessed on 10 August 2020).

Moran, Anthony. 2005. White Australia, settler nationalism and Aboriginal assimilation. Australian Journal of Politics and History 51: 168-93. [CrossRef]

Moreton-Robinson, Aileen. 2000. Talkin'up to the White Woman: Aboriginal Women and Feminism. Brisbane: Univ. of Queensland Press.

Moreton-Robinson, Aileen. 2015. The White Possessive: Property, Power, and Indigenous Sovereignty. Minneapolis: U of Minnesota Press.

Moya, Paula. 2006. Pilgrimages/Peregrinajes: Theorizing Coalition against Multiple Oppressions (review). Hypatia 21: 198-202. [CrossRef]

Nakata, Martin. 2004. Commonsense, colonialism and government. In Woven Histories, Dancing Lives: Torres Strait Islander Identity, Culture and History. Canberra: Aboriginal Studies Press, pp. 154-173.

O'Sullivan, Sandy. 2015. Queering ideas of Indigeneity: Response in repose: Challenging, engaging and ignoring centralising ontologies, responsibilities, deflections and erasures. Journal of Global Indigeneity 1: 5.

O'Sullivan, Sandy. 2016. Recasting identities: Intercultural understandings of First Peoples in the national museum space. In The Routledge International Handbook of Intercultural Arts Research. London: Routledge, pp. 61-71.

O'Sullivan, Sandy. 2019a. A lived experience of Aboriginal knowledges and perspectives: How cultural wisdom saved my life. In Practice Wisdom. Boston: Brill Sense, pp. 107-12.

O'Sullivan, Sandy. 2019b. First nations' women in the academy: Disrupting and displacing the white male gaze. In Strategies for Resisting Sexism in the Academy. Cham: Palgrave Macmillan, pp. 115-27.

O'Sullivan, Sandy. 2021a. Saving lives: Mapping the power of LGBTIQ+ First Nations creative artists. Social Inclusion 9: 61-64. [CrossRef]

O'Sullivan, Sandy. 2021b. The Colonial Project of Gender (and Everything Else). Genealogy 5: 67. [CrossRef]

Oyěwùmí, Oyèrónké. 1997. The Invention of Women: Making an African Sense of Western Gender Discourses. Minneapolis: U of Minnesota Press. 
Simpson, Leanne Betasamosake. 2014. Not Murdered and Not Missing: Rebelling against Colonial Gender Violence. Available online: https://www.versobooks.com/blogs/4611-not-murdered-not-missing-rebelling-against-colonial-gender-violence (accessed on 8 August 2020).

Simpson, Leanne Betasamosake. 2017. As We Have Always Done: Indigenous Freedom through Radical Resistance. Minneapolis: U of Minnesota Press.

Smith, William Ramsay. 1913. Australian Conditions and Problems from the Standpoint of Present Anthropological Knowledge. Canberra: Government Printer, No. 2.

Soldatic, Karen. 2015. Post colonial re productions: Disability, indigeneity and the formation of the white masculine settler state of Australia. Social Identities 21: 53-68. [CrossRef]

Sommerville, Siobhan. 1994. Scientific racism and the emergence of the homosexual body. Journal of the History of Sexuality 5: 243-66.

Sullivan, Corrinne Tayce. 2018a. Indigenous Australian women's colonial sexual intimacies: Positioning indigenous women's agency. Culture, Health and Sexuality 20: 397-410. [CrossRef] [PubMed]

Sullivan, Corrinne Tayce. 2018b. Majesty in the city: Experiences of an Aboriginal transgender sex worker in Sydney, Australia. Gender, Place and Culture 25: 1681-702. [CrossRef]

Sullivan, Corrinne Tayce. 2020. Who holds the key? Negotiating gatekeepers, community politics, and the "right" to research in Indigenous spaces. Geographical Research 58: 344-54. [CrossRef]

TallBear, Kim, and Angela Wiley. 2019. Critical relationality: Indigenous and queer belonging beyond settler sex and nature. Imaginations 10: 1.

Tatonetti, Lisa. 2014. The Queerness of Native American Literature. Minneapolis: U of Minnesota Press.

Veracini, Lorenzo. 2011. Isopolitics, deep colonizing, settler colonialism. Interventions 13: 171-89. [CrossRef]

Wilson, Alex. 2015. Our coming in stories: Cree identity, body sovereignty and gender self-determination. Journal of Global Indigeneity 1: 4.

Wolfe, Patrick. 2008. Structure and Event: Settler Colonialism and the Question of Genocide. In Empire, Colony, Genocide: Conquest, Occupation, and Subaltern Resistance in World History. Edited by A. Dirk Moses. Oxford: Berghahn Books, pp. 102-32. 